\title{
Neurokinin A is the predominant tachykinin in human bronchoalveolar lavage fluid in normal and asthmatic subjects
}

\author{
L G Heaney, L J M Cross, L P A McGarvey, K D Buchanan, M Ennis, C Shaw
}

\begin{abstract}
Background-Multiple sensory neuropeptides are present in human airways and may contribute to diseases such as asthma. This study quantified and characterised substance $P(S P)$, neurokinin $A$ (NKA), and calcitonin gene related peptide (CGRP) immunoreactivity in bronchoalveolar lavage fluid in asthmatic and normal subjects.

Methods-Using specific radioimmunoassay (RIA), SP, NKA and CGRP were measured in bronchoalveolar lavage fluid from asthmatic subjects $(n=5)$, normal subjects $(n=5)$, atopic non-asthmatic subjects $(n=6)$, and asthmatic subjects four hours after allergen challenge $(n=$ 12). Peptide immunoreactivity was characterised using high performance liquid chromatography (HPLC) and RIA.

Results-No SP or CGRP immunoreactivity was detected in any of the fractions from samples after extraction, HPLC, and RIA. Non-specific binding resulted in spurious SP immunoreactivity being detected in bronchoalveolar lavage fluid when no extraction process was employed. NKA was detected in significant amounts in asthmatic (median 550, range 425$625 \mathrm{pg} / \mathrm{ml}$ ) and normal subjects (median 725 , range $350-1425 \mathrm{pg} / \mathrm{ml}$ ). The level of NKA was significantly higher in the asthmatic subjects after allergen challenge (median 750 , range $350-1250 \mathrm{pg} / \mathrm{ml}$ ) than in unchallenged asthmatic subjects (median 600, range $425-600 \mathrm{pg} / \mathrm{ml}, \mathrm{p}<0.01$ ). Conclusions-Extraction and characterisation of peptides from bronchoalveolar lavage fluid must be performed to ensure that the measured immunoreactivity represents target peptide. NKA is present in bronchoalveolar lavage fluid in high concentrations and is the predominant tachykinin. The concentrations of NKA are similar in normal subjects and subjects with mild asthma.

(Thorax 1998;53:357-362)
\end{abstract}

Keywords: neurokinin A; substance P; bronchoalveolar lavage

The diffuse neuroendocrine system consists of specialised endocrine cells and peptidergic nerves and is present in all organs of the body including the respiratory tract. ${ }^{1}$ Peptides can be localised to pulmonary nerves, pulmonary veins, cells of the pulmonary endothelium, and bronchial epithelial endocrine cells. ${ }^{1}$ Peptides localised to nerves can be divided into those that are localised to the parasympathetic and sympathetic nerves in the airways and those that are associated with sensory nerves in the bronchial epithelium. Peptides associated with sensory nerves in humans include the tachykinins substance $P(S P)$ and neurokinin $A$ (NKA) and the related peptide calcitonin gene related peptide (CGRP), and coexist in the same nerve fibres. ${ }^{2}$ Great interest has surrounded these sensory neuropeptides in the respiratory tract since in vitro they cause many of the features of asthma such as bronchoconstriction, mucus secretion, and airway oedema. ${ }^{3}$

Previous studies have measured levels of SP in lavage fluid ${ }^{4-6}$ but the other sensory neuropeptides NKA and CGRP have not been examined. The aim of this study was to measure and characterise SP, NKA, and CGRP-like immunoreactivity in bronchoalveolar lavage (BAL) fluid in normal subjects and subjects with mild asthma. The study also determined whether a difference was observed in peptide levels in asthmatic subjects four hours after allergen exposure.

\section{Methods}

All subjects ( $\mathrm{n}=25$, age range $18-37$ years, table 1) were recruited on a voluntary basis and gave informed written consent to take part in the study, which was approved by the Faculty of Medicine Research ethics committee of The Queen's University of Belfast. Asthma was defined according to the American Thoracic Society as a history of intermittent wheeze, cough, or chest tightness on allergen exposure or exercise. ${ }^{7}$ Subjects were excluded if there was any history of smoking, diabetes, current pregnancy, cardiac or renal disease, or any chest disease other than asthma. Asthmatic subjects had current asthma defined as symptoms within the past 12 months and atopy was defined as positive skin test to one or more of four common environmental allergens (house dust mite (Dermataphagoides pterynonissimus, HDM), mixed grass pollen, cat, and dog; Biodiagnostics). All atopic subjects were sensitive to HDM with a positive skin test and HDM specific IgE in the serum measured by radioallergosorbent test (RAST; Pharmacia Ltd). In atopic subjects sensitive to grasses all studies were performed outside the grass pollen season (May to July). Asthmatic subjects on theophylline, inhaled steroids, or cromoglycate or those who had taken oral steroids in the preceding 
Table 1 Age, sex, atopic status, baseline spirometric indices and subject group

\begin{tabular}{|c|c|c|c|c|c|c|c|c|}
\hline Patient no. & Age (yr) & $\operatorname{Sex}$ & $\operatorname{IgE}(U / l)$ & $\begin{array}{l}\text { RAST } \\
\text { HDM }+\end{array}$ & $\begin{array}{l}P C_{20}{ }^{*} \\
(\mathrm{mg} / \mathrm{ml})\end{array}$ & $\begin{array}{l}F E V_{1}(l) \\
\text { (\% predicted) }\end{array}$ & $\begin{array}{l}F V C \text { (l) } \\
\text { (\% predicted) }\end{array}$ & $E A R \neq(\%)$ \\
\hline \multicolumn{9}{|c|}{ Non-atopic non-asthma } \\
\hline 1 & 21 & $M$ & 12 & 0 & 44.2 & $5.34(113)$ & $7.46(131)$ & \\
\hline 2 & 22 & $M$ & 14 & 0 & 64 & $4.02(92)$ & $5.05(97)$ & \\
\hline 3 & 22 & $\mathrm{M}$ & 57 & 0 & 16 & $3.89(96)$ & $5.46(115)$ & \\
\hline 4 & 21 & M & 6 & 0 & 128 & $5.47(121)$ & $6.44(119)$ & \\
\hline 5 & 21 & $M$ & 7 & 0 & 55 & $4.93(114)$ & $5.81(114)$ & \\
\hline \multicolumn{9}{|c|}{ Atopic non-asthma } \\
\hline 6 & 21 & $M$ & 222 & 2 & 21.8 & $5.35(113)$ & $6.28(113)$ & \\
\hline 7 & 29 & $\mathrm{~F}$ & 174 & 2 & 64 & $4.69(151)$ & $6.26(162)$ & \\
\hline 8 & 22 & M & 137 & 3 & $>128$ & $4.86(106)$ & $5.59(102)$ & \\
\hline 9 & 26 & M & 14 & 2 & 46 & $3.91(96)$ & $5.15(105)$ & \\
\hline 10 & 21 & $M$ & 54 & 3 & 6.4 & $5.62(125)$ & $6.96(129)$ & \\
\hline 11 & 21 & $M$ & 274 & 2 & 32 & $4.71(107)$ & $6.12(118)$ & \\
\hline \multicolumn{9}{|c|}{ Allergen challenged asthma } \\
\hline 12 & 36 & M & 27 & 3 & 0.28 & $3.05(91)$ & $5.15(126)$ & 30 \\
\hline 13 & 28 & $\mathrm{~F}$ & 266 & 5 & 0.2 & $2.38(74)$ & $4.34(108)$ & 37 \\
\hline 14 & 22 & M & 121 & 4 & 0.18 & $3.24(78)$ & $5.86(119)$ & 21 \\
\hline 15 & 23 & $M$ & 159 & 5 & 5.72 & $6.59(155)$ & $8.15(160)$ & 50 \\
\hline 16 & 23 & $M$ & 291 & 4 & 12.9 & $4.29(103)$ & $6.0 \quad(121)$ & 48 \\
\hline 17 & 37 & $\mathrm{~F}$ & 153 & 2 & 0.9 & $2.48(87)$ & $3.73(104)$ & 38 \\
\hline 18 & 18 & $\mathrm{~F}$ & 297 & 6 & 3.17 & $2.73(96)$ & $3.67(114)$ & 41 \\
\hline 19 & 21 & $\mathrm{M}$ & 152 & 3 & 0.8 & 4.79 (108) & 6.59 (128) & 21 \\
\hline 20 & 21 & $\mathrm{~F}$ & 1556 & 6 & 0.45 & $3.41(99)$ & $4.53(99)$ & 52 \\
\hline 21 & 19 & $\mathrm{M}$ & 163 & 4 & 8.4 & $5.3(128)$ & 5.8 (117) & 23 \\
\hline 22 & 22 & M & 802 & 5 & 3.9 & $4.54(103)$ & $5.23(99)$ & 21 \\
\hline 23 & 26 & $M$ & 161 & 4 & 3 & $4.06(104)$ & $5.78(124)$ & 41 \\
\hline \multicolumn{9}{|c|}{ Unchallenged asthma } \\
\hline 24 & 19 & $M$ & 1256 & 6 & 0.5 & $3.95(91)$ & $5.25(102)$ & \\
\hline 25 & 25 & $M$ & 15 & 3 & 7.8 & $4.67(107)$ & $6.9 \quad(132)$ & \\
\hline 18 & 18 & $\mathrm{~F}$ & 297 & 6 & 2.9 & $2.62(96)$ & 5.7 (115) & \\
\hline 19 & 21 & $M$ & 152 & 3 & 1.0 & $4.08(92)$ & $6.18(120)$ & \\
\hline 23 & 26 & $M$ & 161 & 4 & 3.4 & $3.82(96)$ & 4.3 (94) & \\
\hline
\end{tabular}

Three asthmatic subjects (nos 18, 19,23) were studied on two separate occasions (post challenge and unchallenged). *Concentration of methacholine $\left(\mathrm{PC}_{20}\right)$ causing a $20 \%$ fall in $\mathrm{FEV}_{1}$.

†Radioallergosorbent test to house dust mite (RAST HDM) is given as $0-6(0=$ negative, $6=$ strongly positive) $\ddagger \mathrm{EAR}$ is the maximal recorded fall in $\mathrm{FEV}_{1}$ in the first hour after allergen challenge on the day of bronchoscopy.

four weeks were also excluded to ensure recruitment of asthmatic subjects with mild clinical disease and no recent exacerbations. Prior to attending for each study day, asthmatic subjects were advised to omit inhaled $\beta_{2}$ agonists for the preceding 12 hours.

\section{INHALATION CHALLENGES}

Methacholine challenge (Sigma-Aldrich Company Ltd) was performed using the tidal breathing method of Cockroft et al. ${ }^{8}$ Allergen

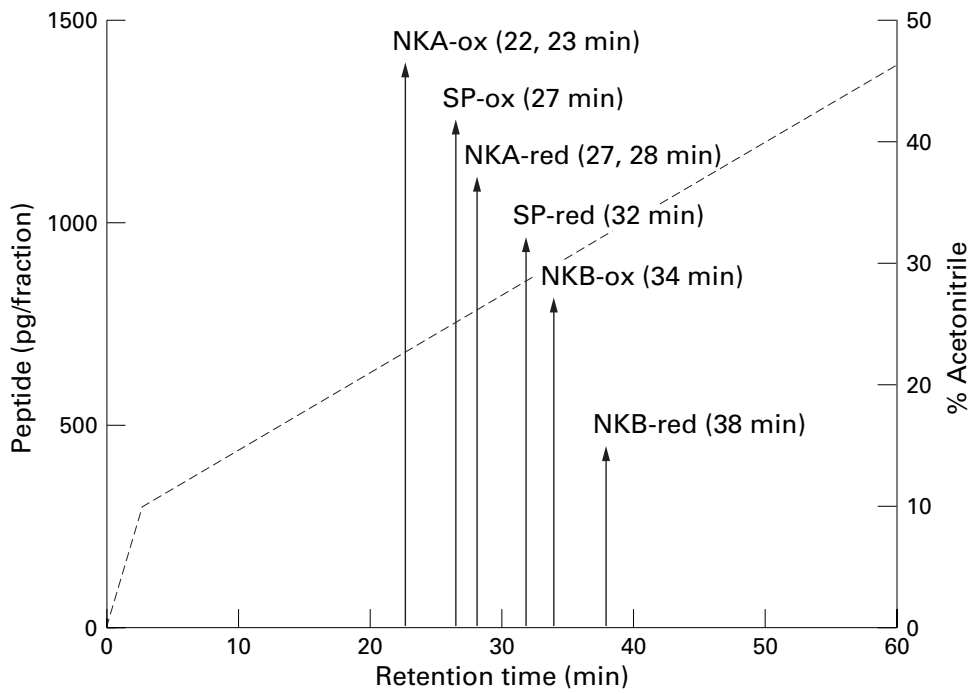

Figure 1 Reverse phase HPLC chromatogram showing retention times for synthetic neurokinin $A(N K A)$, neurokinin $B(N K B)$, and substance $P(S P)$. A $\mu$-Bondapak C-18 reverse phase column was used and was eluted with a gradient from TFA/water (0.1:99.9) to TFA/water/acetonitrile (0.1:89.9:10) in three minutes and then to TFA/water/ acetonitrile (0.1:54.9:45) over the next 45 minutes at a flow rate of $1.5 \mathrm{ml} / \mathrm{min}$. Fractions were collected each minute, lyophilised and reconstituted prior to radioimmunoassay. The suffixes "ox" and "red" refer to oxidised and reduced peptide, respectively. challenge was performed in a similar fashion with inhalation of increasing doses (500 units/ $\mathrm{ml}, 1000$ units/ml, 5000 units/ml HDM antigen solution) until forced expiratory volume in one second $\left(\mathrm{FEV}_{1}\right)$ fell by at least $20 \%$ from the baseline value or the maximum concentration of HDM had been inhaled. Three asthmatic subjects were studied on two separate occasions with and without allergen challenge (subjects 18, 19 and 23, table 1). After initial recruitment and assessment the subject groups were non-challenged asthma (unchallenged, $\mathrm{n}=5$ ), allergen challenged asthma $(n=12)$, atopic non-asthmatic control (ANA, $n=6$ ), and non-atopic non-asthmatic control (normal, $\mathrm{n}=5$ ).

BRONCHOSCOPY AND BRONCHOALVEOLAR LAVAGE On a subsequent day subjects attended for bronchoscopic examination. Challenged asthmatics underwent allergen inhalation challenge with $\mathrm{HDM}\left(\mathrm{PD}_{20}\right.$ allergen) at 08.30 hours. All bronchoscopies were performed at 12.30 hours using a standardised technique. The bronchoscope (Olympus IT20D) was inserted under direct vision via the nasal or oral route and local anaesthesia ( $1 \%$ lignocaine) was administered as required to suppress coughing. The bronchoscope was wedged in the medial or lateral segment of the right middle lobe and bronchoalveolar lavage (BAL) was performed $(3 \times 60 \mathrm{ml}$ aliquots of sterile isotonic phosphate buffered saline, prewarmed to $37^{\circ} \mathrm{C}$ ). The fluid was aspirated and the return samples pooled and placed immediately on ice. 


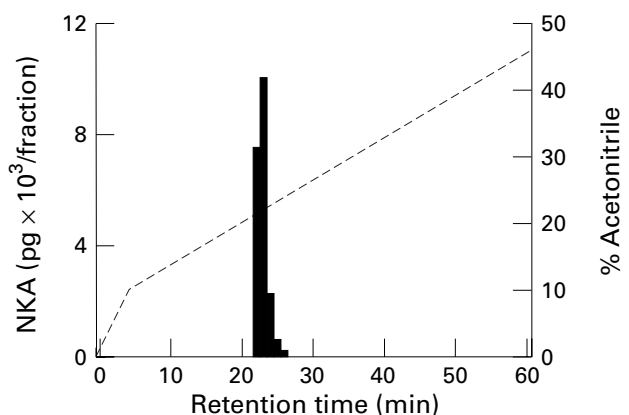

Figure 2 Reverse phase HPLC chromatograms for one subject. Lavage fluid $(10 \mathrm{ml})$ was reconstituted in $0.1 \%$ TFA in water and added to the column. NKA immunoreactivity in the sample eluted at the same time as oxidised NKA.

PROCESSING OF LAVAGE FLUID

The lavage fluid was centrifuged at $200 \mathrm{~g}, 4^{\circ} \mathrm{C}$, for 10 minutes and the cell free supernatant was placed in $9 \mathrm{ml}$ aliquots into polypropylene tubes containing acetic acid $(1 \mathrm{ml}, 2 \mathrm{M})$. To this a protease inhibitor cocktail was added consisting of 1,10 phenanthroline (SigmaAldrich Company Ltd, final concentration $5 \mathrm{mM}$ ), PMSF (Sigma-Aldrich Company Ltd, final concentration $0.5 \mathrm{mM}$ ), and E-64 (Sigma-Aldrich Company Ltd, final concentration $10 \mu \mathrm{M})$. All samples were frozen and stored at $-70^{\circ} \mathrm{C}$.

\section{NEUROPEPTIDE ASSAYS}

\section{$S P$ and $N K A$}

SP-like immunoreactivity was measured using an anti serum (SP-152) highly specific for the whole molecule ${ }^{9}$ which was raised in rabbit to synthetic human SP. It shows no significant cross reactivity with NKA, neurokinin B (NKB), and neuropeptide K (NPK). ${ }^{9} \mathrm{NKA}-$ like immunoreactivity was measured using a C-terminal specific anti-serum (SK-570) which was raised in rabbit to synthetic human NKA. It cross reacts fully with NKB and NPK but less than $0.1 \%$ with SP. ${ }^{9}$ Using monoiodinated, reverse phase HPLC purified tracers the $\mathrm{SP}$ assay can detect $0.5 \mathrm{pg}$ per assay tube and the NKA assay 2 pg per assay tube. ${ }^{9}$

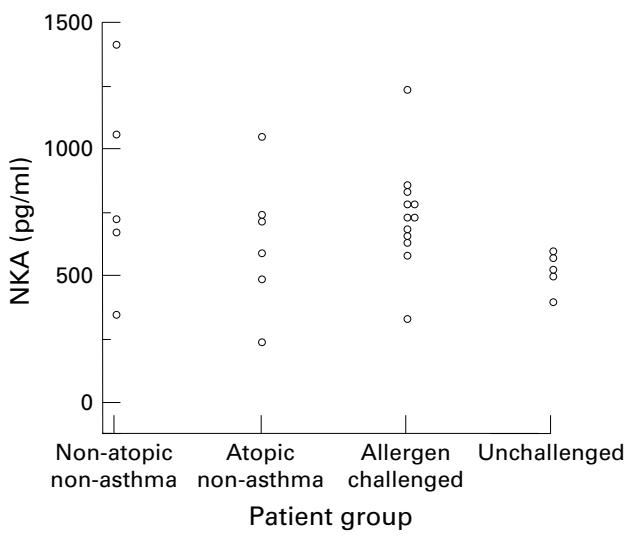

Figure 3 NKA concentrations in lavage fluid for individual subjects. Unchallenged $=$ unchallenged asthmatic subjects and allergen challenged = asthmatic subjects four hours after allergen exposure. Statistical comparison was made using the Mann-Whitney U test. NKA levels were significantly higher in the challenged asthmatic group than in the unchallenged group $(p<0.01)$.

\section{CGRP}

CGRP immunoreactivity was measured using a commercial CGRP human radioimmunoassay (RIA) kit (catalogue number RIK009, Peninsula Laboratories). This antibody is a rabbit anti-human CGRP peptide (II) antibody. The label was ${ }^{125} \mathrm{I}-\mathrm{Tyr}^{0}$-CGRP (catalogue number Y6011). The sensitivity was $45 \mathrm{pg}$ per assay tube and the antibody cross reacts $100 \%$ with human CGRP (II), human CGRP, and rat CGRP. It cross reacts $<0.001 \%$ with rat calcitonin C-terminal adjacent peptide and less than $0.02 \%$ with insulin, glucagon, somatostatin, SP, vasoactive intestinal peptide, and gastrin releasing peptide.

\section{EXTRACTION AND ASSAY}

C18 Sep-pak cartridges (Waters Associates) were used to extract peptides from lavage fluid. Lavage fluid $(10 \mathrm{ml})$ was passed four times through the cartridge to bind peptides to the hydrated gel in the cartridge. The peptides were eluted using $0.1 \% \mathrm{v} / \mathrm{v}$ trifluoroacetic acid (TFA) in acetonitrile and the eluent allowed to evaporate to dryness at room temperature. The samples were then reconstituted in assay buffer (40 mM sodium phosphate $\mathrm{pH} 7.4$ with $2 \%$

Table 2 Substance P (SP) immunoreactivity after assay of raw lavage fluid without employing an extraction process

\begin{tabular}{|c|c|c|c|c|c|c|c|}
\hline \multicolumn{2}{|c|}{ Non-atopic non-asthma } & \multicolumn{2}{|c|}{ Atopic non-asthma } & \multicolumn{2}{|c|}{ Allergen challenged asthma } & \multicolumn{2}{|c|}{ Unchallenged asthma } \\
\hline $\begin{array}{l}\text { Patient } \\
\text { no. }\end{array}$ & $\begin{array}{l}S P-L I \\
\text { pre-extraction } \\
(p g / m l)\end{array}$ & $\begin{array}{l}\text { Patient } \\
\text { no. }\end{array}$ & $\begin{array}{l}S P-L I \\
\text { pre-extraction } \\
(p g / m l)\end{array}$ & $\begin{array}{l}\text { Patient } \\
\text { no. }\end{array}$ & $\begin{array}{l}\text { SP-LI pre-extraction } \\
(p g / m l)\end{array}$ & $\begin{array}{l}\text { Patient } \\
\text { no. }\end{array}$ & $\begin{array}{l}S P-L I \\
\text { pre-extraction } \\
(p g / m l)\end{array}$ \\
\hline 1 & 64 & 6 & 70 & 12 & 50 & 24 & 68 \\
\hline 2 & 332 & 7 & 46 & 13 & 152 & 25 & 72 \\
\hline 3 & 72 & 8 & 148 & 14 & 192 & 18 & 72 \\
\hline 4 & 308 & 9 & 48 & 15 & 112 & 19 & 44 \\
\hline \multirow[t]{8}{*}{5} & 60 & 10 & 56 & 16 & 82 & 23 & 112 \\
\hline & & 11 & 52 & 17 & 68 & & \\
\hline & & & & 18 & 100 & & \\
\hline & & & & 19 & 220 & & \\
\hline & & & & 20 & 82 & & \\
\hline & & & & 21 & 110 & & \\
\hline & & & & 22 & 40 & & \\
\hline & & & & 23 & 100 & & \\
\hline
\end{tabular}

SP-LI=substance P-like immunoreactivity.

Three asthmatic subjects (nos 18,19,23) were studied on two separate occasions (post challenge and unchallenged). No SP immunoreactivity was detected in any samples after extraction and radioimmunoassay or high performance liquid chromatography and radioimmunoassay. 
Table 3 Substance $P(S P)$ recovery after addition of synthetic peptide to three lavage samples

\begin{tabular}{lllll}
\hline Sample & $\begin{array}{l}\text { Initial SP } \\
\text { concentration in } \\
\text { BAL fluid }(p g / m l)\end{array}$ & $\begin{array}{l}\text { Concentration in } \\
\text { BAL fluid after addition } \\
\text { of SP }(p g / m l)\end{array}$ & $\begin{array}{l}\text { Measured SP } \\
\text { concentration }(p g / m l)\end{array}$ & $\begin{array}{l}\% \\
\text { recovery }\end{array}$ \\
\hline 1 & 0 & 400 & 388 & 97 \\
2 & 0 & 400 & 381 & 95 \\
3 & 0 & 400 & 343 & 86 \\
\hline
\end{tabular}

horse serum) and subjected to each assay in serial dilution.

To examine peptide recovery, known concentrations of synthetic peptides were added to lavage samples and extracted and assayed as above.

REVERSE PHASE HPLC

After Sep-pak extraction, lavage samples were reconstituted in $0.1 \%$ TFA in water and added to a $\mu$-Bondapak C-18 reverse phase column (Waters Associates). The column was eluted with a gradient from TFA/water $(0.1: 99.9)$ to $\mathrm{TFA} /$ water/acetonitrile $(0.1: 89.9: 10)$ in three minutes and then to TFA/water/acetonitrile $(0.1: 54.9: 45)$ over the next 45 minutes at a flow rate of $1.5 \mathrm{ml} / \mathrm{min}$. Fractions were collected each minute, lyophilised using a Univap evaporator attached to a refrigerated solvent trap (Unisciences) and a vacuum pump (Savant), reconstituted in assay buffer, and assayed by RIA. The gradient employed had previously been found to resolve synthetic SP, NKA, NKB and NPK. ${ }^{10}$

STATISTICAL ANALYSIS

Comparisons were made using non-parametric methods throughout. The Kruksal Wallis analysis of variance was used to examine for significant intergroup differences and, if significant, the Mann-Whitney U test was used for between group comparison. A p value of less than 0.05 was considered statistically significant.

\section{Results}

REVERSE PHASE HPLC FOR TACHYKININS AND CGRP

SP, CGRP, and NKA immunoreactive peptides were resolved in reverse phase chromatographic fractions using lavage specimens $(10 \mathrm{ml})$. Figure 1 shows the retention times for synthetic human tachykinin peptides previously calibrated using our system. ${ }^{8}$ Figure 2 shows the immunoreactivity in a typical sample (subject 17) for each of the fractions for NKA (which eluted at the same time as oxidised synthetic NKA). No SP or CGRP immunoreactivity was detected in any of the fractions from samples after HPLC and RIA.

Since we were unable to detect SP after HPLC and RIA and other groups have reported detectable SP in assays performed on raw lavage fluid, we assayed SP in all samples of lavage fluid without performing our extraction process and found SP-like immunoreactivity in all samples (table 2). Mean peptide recovery from lavage samples was more than $90 \%$ for all peptides assayed. Table 3 shows recovery data for SP.
RADIOIMMUNOASSAY QUANTITATION OF NKA The concentration of NKA in the different patient groups is expressed as $\mathrm{pg} / \mathrm{ml}$ of $\mathrm{BAL}$ fluid and is shown in fig 3. High concentrations were found in all subjects analysed. There was no significant difference in NKA concentrations between subjects with unchallenged asthma, normal subjects, or atopic nonasthmatics. The highest concentration in an individual patient was in a normal subject (subject 2, $1480 \mathrm{pg} / \mathrm{ml}$ ). However, when unchallenged asthmatics were compared with asthmatic subjects after challenge, NKA was significantly higher in the post challenge group $(\mathrm{p}<0.01)$.

\section{Discussion}

This study shows that the predominant tachykinin retrieved in BAL fluid is NKA which is present in significant quantities. We were unable to detect SP or CGRP using either HPLC or RIA after Sep-pak extraction. The BAL fluid matrix is extremely heterogeneous and assay of raw lavage fluid did demonstrate SP-like immunoreactivity in lavage fluid (table 2). However, after HPLC characterisation SP was not detected, suggesting non-specific binding using our highly specific SP antibody on raw lavage fluid. The loss of immunoreactivity was not due to peptide loss since recovery studies using our extraction process demonstrated loss to be minimal (table 3). This would suggest that an extraction process and characterisation of immunoreactivity are essential when measuring peptides in heterogeneous body fluids and may help to explain the difference between our data and previous reports demonstrating SP-like immunoreactivity in BAL fluid. ${ }^{4-6}$ Our laboratory, in an extensive series of experiments, previously concluded that SP cannot be measured without employing an extraction process. ${ }^{11}$ Takeyama et al measured SP immunoreactivity (SP-I) after Sep-pak extraction in BAL fluid $(6 \times 50 \mathrm{ml})$ from patients with idiopathic pulmonary fibrosis (IPF) and pulmonary sarcoidosis using an enzyme immunoassay. ${ }^{12}$ They detected small amounts of SP-I which were statistically greater in patients with IPF than in normal subjects but the reported normal BAL values are less than those reported in the previous studies. This group characterised this immunoreactivity using HPLC and from the published sample trace it is clear that numerous substances in BAL fluid cross react with their assay. However, some of the SP-I did appear to be due to SP. It is possible that our extraction and assay process could miss small amounts of SP; however, given the recovery of added synthetic peptide (table 2), this is likely to be very small.

The fact that there are significant quantities of NKA present in BAL fluid raises two important issues. The first centres around the exact source of the NKA. Such large quantities are unlikely to be derived solely from a neural source, as previously thought, and may be derived from another cellular source. Variants of vasoactive intestinal peptide have been demonstrated in mouse mast cells and rat 
basophilic leukaemic cells ${ }^{13}$ and immunoreactivity for SP has been reported in enterochromaffin cells from rat caecum, ${ }^{14}$ so the concept of other cellular rather than neuronal production of neuropeptides is not completely novel. A recent study also confirmed cells positive for SP in subjects with vernal keratoconjunctivitis ${ }^{15}$ and preliminary data (not shown) using extracts from BAL cell pellets suggest that NKA in BAL fluid may also be derived from resident airway cells. The second issue centres around the genetic coding for mammalian tachykinins. In mammals two separate genes encode the tachykinins designated tachykinin-1 and tachykinin-2. ${ }^{16} \mathrm{SP}$ and NKA are derived from a common precursor protein encoded by the tachykinin-1 gene. ${ }^{16}{ }^{17}$ Alternative RNA splicing of the tachykinin-1 gene results in three different mRNA transcripts encoding the tachykinin precursor proteins, $\alpha-, \beta-$, and $\gamma$-preprotachykinin-1. ${ }^{16}$ These mRNA codes differ in their exon sequence which in turn results in the translation of different peptide products. The $\alpha$-preprotachykinin- 1 gene consists of seven exons. Exon 3 encodes SP and exon 6 encodes NKA. $\alpha$-Preprotachykinin-1 lacks exon 6 and thus results in the production of SP alone. ${ }^{16} \beta$-Preprotachykinin-1 possesses all seven exons and gives rise to SP and NKA in equimolar amounts or an $\mathrm{N}$-terminally extended NKA, designated neuropeptide $\mathrm{K}^{18}$ $\gamma$-Preprotachykinin-1 lacks exon 4 which encodes for a protein of unknown function and produces SP, NKA and an attenuated molecular form of NPK, designated neuropeptide- $\gamma .{ }^{19}$ Thus, whilst SP can be synthesised from these gene transcripts without NKA, the opposite does not occur. Since our results demonstrated NKA in such large amounts without detectable SP, it raises the possibility that an alternative gene transcript may occur which encodes for NKA only. A recent study has reported different tissue levels of NKA and SP in rat cervical dorsal root ganglia compared with central and peripheral terminations of the same neurones. ${ }^{20}$ The NKA content was less than that of SP in dorsal root neurone and in two peripheral tissues (superior cervical ganglion and ear skin). In a third peripheral tissue, the trachea, equal amounts of NKA and SP were found; however, in the spinal cord there was twice as much NKA as SP. This study suggests that, although SP and NKA are colocalised in neurones, their levels vary independently from tissue to tissue suggesting distinct functional roles.

In vitro, NKA is more potent than SP as a contractor of bronchial smooth muscle suggesting that an NK-2 receptor is likely to be involved. ${ }^{21}$ Another study reported a fourfold increase in NK-2 receptor mRNA expression in the airways of asthmatic subjects. ${ }^{22}$ Asthmatics have increased sensitivity to NKA inhalation which is inhibited by nedocromil sodium. ${ }^{23}{ }^{24}$ This has not been seen consistently with $\mathrm{SP}^{23}$ as bronchoconstriction with this peptide requires large doses in hyperresponsive subjects. ${ }^{25}$ A recent report has examined the effect of passive sensitisation on the in vitro contractile effect of SP and NKA on human bronchi. ${ }^{26}$ Human bronchi incubated overnight with serum from asthmatic patients sensitised to HDM showed an enhanced sensitivity and an enhanced maximal contractile response to both tachykinins, an effect which was independent of changes in the activity of neutral endopeptidase. Thus, sensitised airway smooth muscle is more sensitive to tachykinins. No difference was observed in the concentrations of NKA in lavage fluid between asthmatic and normal subjects which suggests that the differential response to inhalation may relate to alterations in NK-2 receptor expression and other inflammatory effects seen in the allergic airway.

BAL fluid concentrations of NKA were raised in asthmatic subjects after allergen challenge compared with the unchallenged group although they did not differ significantly from normal controls. The study design and small numbers of subjects in each group limit the conclusions which can be drawn from this as lavage was not repeated in the same patients after challenge. However, inflammatory events after allergen exposure may result in increased levels of NKA.

In conclusion, this study shows that NKA is present in BAL fluid in high concentrations and that it is the predominant tachykinin peptide. The concentrations of NKA are similar in normal subjects and subjects with mild asthma. Future work will examine both the exact source and homeostatic role of NKA in normal subjects and its pathogenic role, if any, in asthma and other pulmonary conditions.

The authors would like to thank Davina Fillmore and Claire Erwin for performing the neuropeptide assays. L G Heaney was funded by a Department of Health and Social Services research fellowship and L J M Cross was funded by the Department of volunteers who participated in this study and to the nursing staff volunteers who participated in this study and to the nursing staff
of the bronchoscopy suite of the Royal Victoria Hospital, Belfast of the bronchoscopy suite
for their co-operation.

1 Springall DR, Polak JM. Localization of peptides in the lung. Ann NY Acad Sci 1991;629:288-304.

2 Martling CR. Sensory nerves containing tachykinins and CGRP in the lower airways. Functional implications for bronchoconstriction, vasodilation and protein extravasation. Acta Physiol Scand 1987;Suppl 563:1-57.

3 Joos GF, Pauwels RA. The bronchoconstrictor effect of sensory neuropeptides in man. Ann NY Acad Sci 1991;629: $371-82$

4 Nieber K, Baumgarten CR, Rathsack R, et al. Substance P and beta-endorphin-like immunoreactivity in lavage fluids of subjects with and without allergic asthma. F Allergy Clin Immunol 1992;90:646-52.

5 Nieber K, Baumgarten C, Rathsack R, et al. Effect of azelastine on substance $\mathrm{P}$ content in bronchoalveolar and nasal lavage fluids of patients with allergic asthma. Clin Exp Allergy 1993;23:69-71.

6 Hazbun ME, Hamilton R, Holian A, et al. Ozone induced Hazbun $\mathrm{ME}$, Hamilton $\mathrm{R}$, Holian A, et al. Ozone induced
increases in substance $\mathrm{P}$ and 8-epi-prostaglandin $\mathrm{F}_{\text {in }}$ in airways of human subjects. Am $\mathcal{F}$ Respir Cell Mol Biol 1993;9: ways of hum

7 American Thoracic Society. Committee on Diagnostic Standards, Definitions and Classification of Chronic Bronchitis, Asthma and Pulmonary Emphysema. Am Rev Respir Dis 1962;85:762.

8 Cockroft DW, Killian DN, Melon JJA, et al. Bronchial reactivity to inhaled histamine: a method and clinical survey. Clin Allergy 1977;7:235-40.

9 Maule AG, Shaw C, Halton DW, et al. Tachykinin immunoreactivity in the parisitic flatworm Diclidophora merlangi and its fish host the whiting (Merlangius merlangus): radioimmunoassay and chromatographic characterisation using munoassay and chromatographic characterisation using region-specific substance $\mathrm{P}$ and neurol
Comp Biochem Physiol 1989;94:535-41.

10 Shaw C, Foy WL, Johnston CF, et al. Identification and characterisation of multiple tachykinin immunoreactivities in bovine retina: evidence for the presence of a putative oxidative inactivation system for substance P. $\mathcal{F}$ Neurochem 1989;53:1547-54. 
11 Abdulah AR. The measurement of substance $\mathrm{P}$ by radioimmunoassay. PhD Thesis, Belfast, 1984

12 Takeyama $\mathrm{M}$, Nagai S, Mori K, et al. Substance P-like immunoreactive substance in bronchoalveolar lavage fluids from patients with idiopathic pulmonary fibrosis and pulmonary sarcoidosis. Sarcoidosis Vasculitis and Diffuse

13 Wershil BK, Turck CW, Sreedharan SP, et al. Variants of vasoactive intestinal peptide in mouse mast cells and rat basophilic leukaemic cells. Cell Immunol 1993;151:369-78.

14 Simon C, Portalier P, Chamoin MC, et al. Substance P likeimmunoreactivity release from enterochromaffin cells of rat medium. Neurochem Int 1992;20:529-36.

15 Fujishima H, Takeyama M, Takuchi T, et al. Elevated levels of substance $\mathrm{P}$ in tears of patients with allergic conjunctivitis and vernal keratoconjunctivitis. Clin Exp Allergy 1997;27:372-8

16 Nawa $H$, Kotani $H$, Nakanishi $S$. Tissue specific generation of two preprotachykinin mRNAs from one gene through alternative RNA splicing. Nature 1984;312:729-34.

17 Kotani H, Hoshimaru M, Nawa $\mathrm{H}$, et al. Sequence analysis of cloned cDNA for rat substance P precursor. Biochem Biophys Res

18 Tatemoto K, Lundberg JM, Jornvall $\mathrm{H}$, et al. Neuropeptide $\mathrm{K}$ : isolation, structure and biological activities of a novel brain peptide. Biochem Biophys Res Commun 1985;128: 947-53.
19 Kage R, McGregor GP, Thim L, et al. Neuropeptidegamma: a peptide isolated from rabbit intestine that is derived from gamma-preprotachykinin. F Neurochem 1988; 50:1412-7.

20 Bakhle YS, Bell C. Neurokinin A and substance P vary independently in different regions of rat sensory neurons. Neuropeptides 1994;28:237-41.

21 Advenier C, Naline E, Toty L, et al. Effects on the isolated human bronchus of SR 48968, a potent and selective nonpeptide antagonist of the neurokinin A (NK2) receptors. Am Rev Respir Dis 1992;146:1177-81.

22 Bai TR, Danyi Z, Weir T, et al. Substance $\mathrm{P}\left(\mathrm{NK}_{1}\right)$ - and neurokinin A (NK2)-receptor gene expression in inflammatory airway diseases. Am $\mathcal{F}$ Physiol 1995;269:309-17.

23 Joos G, Pauwels R, van der Straeten M. Effect of inhaled substance $\mathrm{P}$ and neurokinin $\mathrm{A}$ on the airways of normal and asthmatic subjects. Thorax 1987;42:779-83.

24 Crimi N, Palermo F, Oliveri R, et al. Protection of nedocromil sodium on bronchoconstriction induced by inhaled neurokinin A (NKA) in asthmatic patients. Clin Exp Allergy 1992;22:75-81.

25 Crimi N, Palermo F, Oliveri R, et al. Effect of nedocromil on bronchospasm induced by inhalation of substance $P$ in bronchospasm induced by inhalation of substanc
asthmatic subjects. Clin Allergy 1988;18:375-82.

26 Ben-Jebria A, Marthan R, Rossetti M, et al. Effect of passive sensitisation on the mechanical activity of human isolated bronchial smooth muscle induced by substance P, neurokinin A and VIP. Br f Pharmacol 1993;109:131-6. 